\title{
JUSTICE WILLIAM BRENNAN JR : "CONSTITUTIONAL VISIONS TAKE FIVE VOTES"
}

\section{Patricia Lucie}

Justice William Brennan died on 24th.July, 1997 aged ninety one, leaving constitutional discourse in America much the livelier for his thirty three years on the Supreme Court. When he joined the Court in 1956, many Americans were still afraid to speak out against McCarthyism. At that time the states still defined the content of a person's rights and these did not necessarily include the right to counsel in a criminal case, to marry the person of your choice or have your vote count equally with that of your neighbour. The first faltering steps towards desegregating schools had been taken just before Brennan joined the Court but racial equality was not on the agenda and gender equality was not even contemplated outside radical circles. What amounted to a revolution in civil rights in the years that followed was not the single handed work of William Brennan, but no other hand contributed more to building a constitutional base for social change. He was a technically brilliant lawyer, and one who was mindful of the law's restraining as well as its energising forces. Nevertheless he read the Constitution in the light of contemporary life as well as the intentions of its Framers, in the light of its spirit as well as by the dictionary and in the light of an old saying of Oliver Wendell Holmes that "it is perfectly proper to regard and study law as a great anthropological document." Its central meaning was never unclear to him. It was to secure the blessings of liberty and equality. How much of these, how far, and in the face of what competing interests is of course the stuff of conflict and Justice Brennan was sometimes on the winning side of hard fought decisions and sometimes left to

* Director, William J.Brennan Project, the University of Glasgow.

${ }^{1}$ Quoted in William J.Brennan, "Law and Social Sciences Today" The Gaston Lecture, Georgetown University, 25th.November, 1957. 


\section{DENNING LAW JOURNAL}

hone his skills as one of the great dissenters of American constitutional law. Unsurprisingly, his legacy is one which includes great liberty enhancing opinions which may be modified in the future but not overlooked, some great dissents which he died hoping would one day become law, and some very divided views on his liberal jurisprudence, though not on the man himself. He was loved by everybody who knew him.

Born the second of eight children of an Irish immigrant family in 1906, William Brennan was living proof of the reality behind the American fairy tale, the talented youngster brought up in the school of hard knocks and strong family loyalties, who had an instinctive as well as intellectual belief in opportunity, civic virtue and above all in the equal dignity and worth of all people. He carried the name William Brennan Junior with more pride than any noble title because it welded him to a father he loved and to generations of Irish history taking root in a promised land. ${ }^{2}$ When he was in his eighties and just before he retired from the Court, he visited Ireland and Scotland, and confirmed his lifelong affinity with his Celtic heritage and enjoyment of the wonderful single malts produced in both countries!

Educated at Pennsylvania's Wharton School of Finance and Commerce and later at Harvard Law School, Brennan's legal career began with a solid professional base in Pitney, Hardin and Skinner and a developing expertise in labour law before he went on to serve on New Jersey's state judiciary, where his talents were rewarded with advancement to the state Supreme Court. It was an interesting time in the state's judicial history, as the great Arthur T.Vanderbilt reformed and modernised the courts, welcoming the contribution of the energetic, personable Brennan who liked nothing better than to work in times of change with a colleague of vision. Later Brennan was often asked if he had learned anything as a state court judge which helped him later on the United States Supreme Court. Curiously, very few Supreme Court justices have advanced by this route. Brennan was only the third in the twentieth century, following the great Holmes and Cardozo. "Apparently the Presidents who have appointed Justices in this century have not valued state court service too highly," he said later, too modest to draw attention to what a loss this was, given the quality of that trio. ${ }^{3} \mathrm{He}$ believed that experience as a state judge was

${ }^{2}$ Nat Henoff, "Profiles:The Constitutionalist" New Yorker Magazine, 12th.March, 1990 is an excellent study of early influences.

${ }^{3}$ William J. Brennan, "State Court Decisions and the Supreme Court" - a speech to the Pennsylvania Bar Association, Pittsburgh, 3rd.February, 1960. 


\section{JUSTICE WILLIAM J. BRENNAN JR}

quite different and not altogether the best preparation. He wrote of an altered perspective that comes when charged with the finality of interpreting the Constitution. Where once he had been suspicious of some federal court interventions in cases competently handled by the state courts, later he became the most active of all his federal colleagues in expanding federal habeas corpus jurisdiction to teach state courts higher standards of procedure in criminal cases. If it did not endear him to a lot of state judges, he at least spoke with the authority of having seven years of close encounters with the realities of state court business.

In 1956 President Eisenhower appointed him to the Supreme Court. If there was any truth in the oft told story that he later felt he had made a mistake, believing that this useful moderate appointment of a Democrat would help him win Irish immigrant votes in New Jersey and discovering that instead he had moved a radical Trojan Horse to conservative Washington, seven more Presidents would live to either bless or curse Ike's gift before Brennan retired in 1990. What he did in these years bears critical examination. If his opinions expanded press freedom, shaped thorough going reforms of criminal procedure, gave real meaning to the equal protection clause's promises to black and female Americans, freed speakers from restraints, and created access to courts and administrative hearings for millions of Americans to pursue their rights, did he not also do this at a price? Did he distort federalism? Was the price of exuberant individualism the loss of collective and family values? Was the price of equality paid by white and male Americans? Was the final cost one to judicial method, turning law into politics?

Justice Brennan's understanding of federalism was inseparable from his understanding of the Bill of Rights. Believing that it was the primary duty of both state and federal governments to honour all of its guarantees of freedom, he joined enthusiastically in the Court's opinions imposing new limitations on the states in criminal trials. Historically, the Bill of Rights had been understood to apply to the actions of the federal government but leaving the states free to fashion their own criminal procedures restrained only by their own state constitutions. It was a freedom which Justice Brennan and his liberal colleagues believed had been often abused. ${ }^{4}$ Poor and black defendants were at the mercy of police methods and rules on admissibility of evidence which were generous to the state's case and parsimonious about rights against self incrimination,

"William J.Brennan, "The Bill of Rights and the States" The James Madison Lecture, New York University, 15th.February, 1961. 


\section{DENNING LAW JOURNAL}

freedom from unreasonable search, and other essential aspects of due process. The poor had no right to appointed counsel. From the 1930s onward, the Supreme Court had begun to apply the specific guarantees in the Bill of Rights to the states and this process of "nationalising" rights gathered pace in the 1960 s. States were obliged to appoint counsel for indigents, to observe strict limitations on the admissibility of evidence contaminated by failure to comply with the fourth and fifth amendments, to provide speedy trials, and in short, to observe all the guarantees of a fair process. ${ }^{5}$ Justice Brennan's special contribution lay in expanding federal remedies to encourage state compliance.

In 1963, in a decision which he rated as one of his most important, Fay v. Noia, his controversial interpretation of the 1867 Habeas Corpus Act swept away procedural obstacles to state prisoners seeking a hearing in a federal court on the grounds that they were imprisoned because the state had violated a right held under the federal Constitution. ${ }^{6}$ This opinion was the first of several which heralded a very significant expansion of federal remedies to state prisoners and a great deal of new business for the federal district and circuit courts. Justice Brennan was proud of this work. He believed that the federal courts were the very arteries of the Bill of Rights. Rather than casting them as the bullies of the federal system, intervening needlessly in state business, he saw them as the dominies of federalism, involved in a dialogue between state and nation with the Bill of Rights as class text. After all, the states which learned best how to protect the rights of the accused would seldom see a decision of its courts overturned on federal habeas corpus. His critics, and there were many, argued that the expanded availability of federal review made prisoners restless and litigious, and that it insulted state judges, undercutting the finality of their decisions and robbing states of their autonomy. Justice Brennan lived to see some of his work undone. Indeed the battle for habeas began in the 1970s when the Court began to steer to the right. In the 1990s Fay v. Noia was effectively overruled by the Court, and Congress itself limited habeas in the 1996

${ }^{5}$ Mapp v. Ohio 367 U.S. 643 (1961) made the exclusionary rule of the fourth amendment applicable to the states; prohibition on cruel and unusual punishments, Robinson v. California 370 U.S. 660 (1962); right to counsel in Gideon v. Wainwright 372 U.S. 335 (1963); prohibition of self incrimination in Malloy v. Hogan 378 U.S. 1 (1964); inadmissibility of confessions in absence of warnings of right to silence and to counsel during questioning in Miranda v. Arizona 384 U.S. 436 (1966); right to jury trial in criminal case in Duncan v. Louisiana 391 U.S. 145 (1968); double jeopardy in Benton v. Maryland 395 U.S. 784 (1969)

${ }^{6} 372$ U.S. 391 (1963). 


\section{JUSTICE WILLIAM J. BRENNAN JR}

Terrorism and Effective Death Penalty Act. ${ }^{7}$ Justice Brennan greatly regretted that, but drew comfort from the substantial body of Warren Court opinions which have survived and especially from the thirty years of education which had yielded higher standards of trial procedure in the states.

It was by no means a paradox when this advocate of strong federal power to guarantee rights latterly became known as the foremost advocate of a revived state constitutionalism. In 1977, in one of the most cited law review articles of all time, Justice Brennan lamented the erosion of rights which was the consequence of the work of a more conservative Supreme Court and he turned to the states to lead the way forward. ${ }^{8}$ There was, he argued, no reason why the states could not provide higher standards of rights protection through their own constitutions than the federal constitution. State judiciaries offering better protection for free speech than the first amendment currently demanded could make their decisions safe from federal review by resting them on "adequate and independent state grounds," a doctrine which he had attacked fiercely in Fay when it had been used by the states to shield a denial of individual rights! Some critics smelled the cynical jurisprudence of lost votes in what seemed to be a convenient about- turn brought on by being on the losing side now. ${ }^{9}$ Yet there was no inconsistency. His argument was that the Bill of Rights was a floor below which the states were forbidden to fall. It was not a ceiling. When travelling above its protections, the "state laboratories are once again open for federal business." His new faith in state constitutionalism was consistent, too, with his emphasis on persuasion and dialogue about rights, though with the states as dominies this time. Time will tell how many of them will answer Justice Brennan's call, and a lively debate goes on still about the health and prospects of state constitutional law as a cutting edge of human rights. Before Brennan, it was never even a question.

${ }^{7}$ Antiterrorism and Effective Death Penalty Act, 28 U.S.C. 2241 et seq. Among important decisions cutting back on habeas, Coleman v. Thompson 501 U.S. 722 (1991) on procedural default, and McCleskey v. Zant 499 U.S. 467 (1991) severely restricting 'successive' applications.

${ }^{8}$ William J. Brennan, "State Constitutions and the protection of Individual Rights" 90 Harv.L.Rev. 489 (1976-77). Justice Brennan noted his satisfaction with subsequent developments in "The Bill of Rights and the States: The Revival of State Constitutions as Guardians of Individual Rights" The James Madison Lecture, New York University, 18th. November, 1986.

${ }^{9}$ Earl M.Maltz, "False Prophet, Justice Brennan and the Theory of State Constitutional Law" 15 Hastings Const.L.Q. 429 (1987-88). 


\section{DENNING LAW JOURNAL}

For William Brennan the Bill of Rights was not an abstraction to be played out in the arena of an equally abstract federalism. The individual was right at the centre. Each and every individual was entitled to equal dignity, respect and value. Translated into hundreds of his opinions, this meant some controversial things, including the right of a newspaper to publish just about anything about a public person, the right of a protester to burn the American flag, and a prohibition on prayer in the classroom. His dissenting opinions caused even more insomnia, contemplating a liberty of homosexuals to indulge in sodomy, a freedom to fill airwaves with "Dirty Words", and even an America without the death penalty. It was hardly surprising that conservatives criticised the outcomes, or that they should ask where he got some of his answers from in history, precedent and text. The old Warren style liberalism has come under attack too from communitarians. ${ }^{10}$ Brennan's vision was of a rights bearing individual in potential conflict with a powerful government, state or federal, sometimes needing protection from government and sometimes needing the power of one government to protect her from another. Was the result a rampant individualism at the expense of community, and the erosion of school, family and state in the making and keeping of shared values?

Justice Brennan's opinions do not lack sensitivity to communities, though they often evince an awareness of the vulnerability of those who do not conform or share the race or creed of the majority in a local environment. His role in keeping God out of the classroom, for example, was to fulfil the first amendment's promise to Native American Indians, Hindus and Jews as well as Christians that there would be no establishment of religion and that they would enjoy free exercise of religion. The only safe unit to entrust, however, in order to leave tribes, sects and churches to keep traditions and faiths was the individual. He was a devout Catholic in his private life. Dissenting in Lynch $\mathrm{v}$. Donnelly to the proposition that a Christian nativity scene displayed in a public place was not a violation of the establishment clause because there were so many reindeers and clutter around it as to make it effectively secular, Justice Brennan did not attack the community feeling that put it there, but instead protected a message which he said was "best understood as a mystical recreation of an event that lies at the heart of the Christian faith. To suggest that such a symbol is merely 'traditional' and therefore no different from Santa's house or reindeer is offensive to those for whom the creche has profound

${ }^{10}$ Robert C. Post, "Justice Brennan and Federalism" 7 Constitutional Commentary 227 


\section{JUSTICE WILLIAM J. BRENNAN JR}

significance." It is hard to see how community values are compromised by a deep respect for faith, inclusive of all faiths. In Brennan's view, official selection of messages by school or community compromised a value selected by the Constitution.

Few other Justices have made such an impact on the balance of rights between family, state and child. Whilst Brennan affirmed that the foetus has no rights by his unflagging support for Roe v. Wade ${ }^{12}$ and his contribution to the abortion debate, he helped to create the rights bearing child. He supported the Court's decisions that minors seeking an abortion were not obliged to obtain parental consent, and also broke new ground in a plurality opinion in Carey v. Population Services in 1977, striking down New York's ban on the sale or distribution of contraceptives to minors under sixteen and arguing for strict scrutiny of state restrictions on contraception. ${ }^{13}$ Access to contraceptives, even for the young was "essential to the exercise of the constitutionally protected right of decision in matters of childbearing." In Brennan's many opinions concerning the rights of the child, he acknowledged that children have constitutional rights, but not in exact measure with adults. Context was important. A child might have a first amendment right to use language containing sexual innuendo in some circumstances, but not necessarily to escape discipline when he used it in a school speech. ${ }^{14}$ Often his argument was for representation of a child's interests separate from that of the state or the parents, notably in delinquency cases where the child stood to lose her freedom, or where parents sought the committal of the child to a mental institution. ${ }^{15} \mathrm{He}$ consistently argued that the law should not penalise children because their parents were unmarried or had an unconventional lifestyle, or deny them an education because their parents were undocumented aliens. ${ }^{16}$

11465 U.S. 668 (1984).

12410 U.S.113 (1973).

13431 U.S. 113 (1977).

${ }^{14}$ Bethel School District, No.403 v. Fraser 478 U.S. 675 (1986) concurring opinion.

${ }^{15}$ Parham v. J.R. 442 U.S. 584 (1979), part dissenting. See Burt, "The Constitution and the Family" 1979 Sup.Ct.Rev. 329 for a critique of Brennan's faith in court resolution.

${ }^{16}$ Pickett v. Brown 462 U.S. 1 (1983) on illegitimacy and equal protection; Michael H. v. Gerald D. 491 U.S.110 (1990) on unconventional family relationships and due process; Plyer 


\section{DENNING LAW JOURNAL}

Brennan's rights bearing child was not intended to be a threat to the community or the family, however. He reasoned that the child was the future citizen, and that in addition to protection she needed respect and choice. Hence he argued for access to ideas and information, and sometimes to lawyers and courts rather than parents. Where rights were concerned he was usually to be found on the side which argued for the treatment of young people as mature, responsible individuals. There was one notable exception. In Stanford $v$. Kentucky in 1989, a majority on the Court concluded that children as young as sixteen who kill, were eligible for the death penalty. ${ }^{17}$ Justice Scalia argued that children knew right from wrong, that their moral culpability was a matter for individual assessment and that there was no national consensus against executing them. Justice Brennan argued that juveniles as a class were less morally culpable and aware of consequences, and more likely than adults to be rehabilitated. He would thus excuse them as a class rather than as individuals from death row. In the sense that he had never argued an identity of rights between adults and children, it was not an inconsistent position to argue that juveniles had a lesser responsibility. He never of course wavered from his lifelong belief, expressed most comprehensively in Furman v. Georgia in 1972 that capital punishment was a violation of the eighth amendment's prohibition of cruel and unusual punishment, arguing that "Death is today an unusually severe punishment, unusual in its pain, in its finality and in its enormity."18

Justice Brennan's vigorous defence of individual rights did not indicate a lack of faith in democracy but was a manifestation of it. Nowhere is this better illustrated than in his opinions concerning freedom of speech and press. To Justice Brennan the first amendment was the cornerstone of self government. It created the conditions of informed debate and reached into every aspect of the life of the mind, including the emotions and senses as well as the intellect. His best known opinion is New York Times Co. v. Sullivan in 1964, holding that criticism of the public conduct of officials was protected by the first amendment even if the statement contained falsity, unless it was made with

v. Doe 457 U.S.202 (1982) on education and equal protection.

17492 U.S.A.361 (1989).

18408 U.S. 238 (1972) at 287. Justice Brennan and his colleague Justice Thurgood Marshall dissented in every case thereafter imposing the death penalty, citing their respective opinions in Furman. 


\section{JUSTICE WLLIAM J. BRENNAN JR}

"actual malice." 19 One of America's best known theorists of free speech, Alexander Meiklejohn, thought the opinion gave cause for "dancing in the streets." ${ }^{20}$ It was not a perfect opinion. Juries have found difficulty with the "actual malice" test, courts have found difficulty in drawing lines between public and private people, and newspapers have complained of expensive discovery costs. Nevertheless it signalled the end of restrictive libel laws which chilled informed discussion and the beginning of an era in which the press has enjoyed a great freedom, to investigate, expose and criticise. If it has not always produced a high quality of debate and concerns raised thirty years after Times have focussed on the intrusion of the press into privacy. The Court has not yet had the opportunity to deal with the issues directly. It may be guessed that Justice Brennan would have been cautious about abridging press freedom to accommodate privacy. He consistently upheld publication of the names of juveniles and rape victims where these were available on court record. In a dictum in a 1967 case, Time Inc. v. Hill, he wrote that "newsworthiness" could offer protection to the press from liability in a case involving invasion of privacy. ${ }^{21}$ In this area, Justice Brennan made openness and access to information a priority, possibly over a competing individual right to privacy.

Justice Brennan made as great an impact on the equal protection clause of the fourteenth amendment as he did on the rest of the Bill of Rights. It was he who first put the word "NOW" into the vocabulary of school desegregation when the Court's patience with Southern non-compliance wore thin in Green v. County School Board in $1968 .{ }^{22}$ He was a strong advocate of using the strictest standard of judicial review to unmask and uproot racial discrimination, but he came to the view that the Court need be less suspicious of laws and programmes designed to benefit minority races. In Regents of the University of California v. Bakke, he set out a considered and workable strategy for reviewing affirmative action programmes under a less strict judicial standard, thus freeing colleges and employers to set about recruiting members of

${ }^{19} 376$ U.S. 254 (1964). Anthony Lewis, Make No Law: The Sullivan Case and the First Amendment (N.Y., Random House, 1991) is an excellent study of the case and aftermath.

${ }^{20}$ Meiklejohn's comment reported in Kalven, "The New York Times Case: A Note on the Central Meaning of the First Amendment" 1964 Sup.Ct.Rev. 191.

${ }^{21} 385$ U.S. 374 (1967).

22391 U.S. 430 (1968). 


\section{DENNING LAW JOURNAL}

minorities on preferential terms. ${ }^{23} \mathrm{He}$ wrote for a plurality on this point, and not for a majority. His arguments triggered a debate on and off the Court, with supporters arguing that affirmative action was a necessary, albeit temporary, scaffolding until minorities achieved real equality, and opponents arguing that it was divisive, that it benefitted individuals who had not suffered discrimination personally, stigmatised them by suggesting they could not succeed on merit, and discriminated against whites who were not proven to have discriminated against anybody themselves. Until Brennan retired, the Court continued to debate, and despite new and more conservative appointments, often upheld affirmative action programmes. Indeed Justice Brennan wrote the majority opinion in one such case in 1990, a Congressional scheme for benefitting minorities in broadcasting, in Metro Broadcasting v. F.C.C. ${ }^{24}$ Since his retirement it seems that affirmative action has gone out of fashion. Justice Brennan seldom became downhearted when he witnessed reversals or erosions of his opinions, believing that the life of the law was a longer one than even his ninety one years and that good arguments would not stay down. ${ }^{25}$

Gender equality was a latecomer to the American Constitution but Justice Brennan did much to ensure that it will stay. Reviewing the history of sex discrimination in America, he came to the conclusion in Frontiera v.

Richardson that it should be treated just like race, as a suspect classification, a way of differentiating between people which could only be justified by the state's most compelling interests. ${ }^{26}$ His nation had, he said, "a long and unfortunate history of sex discrimination. Traditionally, such discrimination was rationalised by an attitude of 'romantic paternalism' which, in practical

${ }^{23} 438$ U.S. 265 (1978). Justice Brennan was joined by Justices White, Marshall and Blackmun in his opinion that an 'intermediate' standard of review was a more appropriate standard of review than 'strict scrutiny' where race was used as a benign classification. Two years later a Court majority adopted Brennan's reasoning to uphold a Congressional plan of affirmative action in the construction industry - Fullilove v. Klutznick 448 U.S. 448 (1980).

${ }^{24} 497$ U.S. 547 (1990). It was overuled in Adarand Constructors, Inc. v. Pena 115 S.Ct. 2097 (1995).

${ }^{25}$ Sturm and Guinier, "The Future of Affirmative Action" 84 Cal.L.Rev. 953 and Sunstein, "Public Deliberation, Affirmative Action and the Supreme Court" 84 Cal.L.Rev. 1179 for a discussion of alternative strategies for reviving it.

${ }^{26} 410$ U.S. 677 (1973). 


\section{JUSTICE WILLIAM J. BRENNAN JR}

effect, put women, not on a pedestal, but in a cage." Although a majority of the Court agreed with the result in this case, Brennan narrowly failed to win a majority for his argument that gender, like race is "suspect." His colleagues preferred to await the outcome of the Equal Rights Amendment to the Constitution which was in the process of ratification at the time. They would have waited a long time. The ratification period ended in 1982 without attracting the requisite votes. Meanwhile Justice Brennan had the opportunity to reshape this area of law by articulating a new standard of heightened review, with a majority of colleagues in agreement. The case, Craig v. Boren has become the benchmark of a whole new jurisprudence of twenty years standing, and has been used recently to scrutinise gender differences as strictly as racial ones in all but name, though affirmative action for women may be a casualty of the same trends as in race. ${ }^{27}$

In a long career spanning thirty three years, he wrote a remarkable number of benchmark opinions which remain the law, some more weatherbeaten than others. There were times when he was on the losing side, only to find that Congress recast the law in ways which reflected his opinions. One example is the Religious Freedom Restoration Act, which rescued the essence of Brennan's opinion in Sherbert v. Verner when that 1963 judgement reviewing state laws burdening free exercise of religion by a strict "compelling interest" standard was overruled by Scalia's opinion for the Court in Employment Division of Oregon v. Smith. ${ }^{28}$ Sometimes of course, Brennan opinions were greeted by a howl of Congressional disapproval, as when he held that it was "bedrock principle" of the first amendment that allowed one Gregory Johnson to set fire to the American flag. ${ }^{29}$ Justice Brennan gave Congress its place in the ordered scheme of liberty, but did not draw back from interpreting the Constitution in ways which displeased majorities. Nor would he defer to the "original intention" of the Framers in the work of interpretation. He interpreted

${ }^{27} 429$ U.S. 190 (1976). A recent case in which the Craig standard was used in a manner close to 'strict scrutiny' was U.S. v. Virginia 116 S.Ct. 2264 (1996), striking down Virginia Military Institute's exclusion of women.

${ }^{28}$ The Religious Freedom Restoration Act, Pub.L.No.103-141; 42 U.S.C. $\$ 2000$ bb has, as one of its stated purpose, "to restore the compelling interest test as set forth in Sherbert v. Verner 374 U.S. 398." Employment Division v. Smith 494 U.S. 872 (1990) prompted the response. His colleague, Justice Harry Blackmun provides many more examples in "A Tribute to Mr.Justice Brennan" 26 Harv.C.R.-C.L.L.Rev. 1 (1991).

${ }^{29}$ Texas v. Johnson 491 U.S. 397 (1989). 


\section{DENNING LAW JOURNAL}

the design and purpose of the Constitution as one intended to secure liberty by trusting it to future generations. The design included a very important role for the Court as ultimate interpreter of the Constitution and he welcomed it. "The ultimate question must be, what do the words mean in our time," he wrote. Such a role for the judiciary is bound to attract questions as to the role of value judgements in the process of interpretation but as Justice Brennan argued in a speech at Georgetown in 1985, attributing meanings to dead Framers or traditions does not remove value judgements. ${ }^{30}$

Perhaps the greatest disappointment of his career was to witness the revival of capital punishment in America so soon after Furman v. Georgia seemed to foretell its extinction. Already convinced that it was per se unconstitutional and an affront to human dignity, he remained on the Court long enough to despair of his colleagues' attempts to square the procedures with due process and equal protection. When he retired, he believed it was just as much a lottery as it had been when the Court struck down Georgia's scheme in Furman for its resemblance to lightning. In vain he and Justice Thurgood Marshall raged in bitter dissents, unable to stop the Court from upholding Georgia's overtly racially discriminatory scheme, or from confirming the eligibility of juveniles and mentally retarded people for execution. Unusually he kept up the rage in public after he left the bench, aware that the work to abolish the death penalty was a mountain. "The final labor, it seems, will be left to the brave and able hands and minds of those we leave behind," he wrote in $1994 .^{31}$

The University of Glasgow is proud to have had Justice Brennan as a friend. In 1989, a year before he retired, he came to Glasgow to receive an Honorary LL.D. The visit was an overwhelming success. He charmed everyone who met him. Lord McCluskey and he debated the issue as to whether the United Kingdom should have a Bill of Rights, before an audience which included many who were then actively engaged in considering Scotland's constitutional future. Justice Brennan was optimistic. While he realistically admitted some of America's failures, he did not believe that we should be paralysed by fears about the politicisation of the judiciary. It would be, he thought, a rich

${ }^{30}$ William J.Brennan, "The Constitution of the United States: Contemporary Ratification" Text and Teaching Symposium, Georgetown University, Washington D.C., 12th.October, 1985. For outspoken criticism of Justice Brennan's interpretative method, see "What Brennan Wrought" The New Republic, 13th.August, 1990.

31 "Neither Victims Nor Executioners" 8 Notre Dame J.L. Ethics \& Pub.Pol'y 1 (1994) at 9 . 


\section{JUSTICE WILLIAM J. BRENNAN JR}

opportunity for dialogue and awareness of the value of human rights. Later he came to the School of Law on a sunny July day and took questions from the students. "Where does the right to abortion come from...it isn't in the Constitution?" "How did you feel about all the uproar last week when you wrote the opinion about flagburning?" "Is it difficult to work with Justice so and so?" His patience and tact were memorable, and so too was the sense of listening to someone who made a difference to history. To honour him, about twelve Glasgow students visit the United States each year under the auspices of the University's Brennan Project, to work with organisations representing capital defendants. 